\title{
Defective TNF- $\alpha$-mediated hepatocellular apoptosis and liver damage in acidic sphingomyelinase knockout mice
}

\author{
Carmen García-Ruiz, ${ }^{1,2}$ Anna Colell, ${ }^{1}$ Montserrat Marí, ${ }^{1}$ Albert Morales, ${ }^{1}$ María Calvo, ${ }^{3}$ \\ Carlos Enrich, ${ }^{3}$ and José C. Fernández-Checa ${ }^{1,2}$ \\ ${ }^{1}$ Liver Unit, Instituto de Malalties Digestives, Hospital Clinic i Provincial, Instituto de Investigaciones Biomédicas \\ August Pi Suñer, Barcelona, Spain \\ ${ }^{2}$ Department of Experimental Pathology, Instituto de Investigaciones Biomédicas de Barcelona, Consejo Superior \\ Investigaciones Científicas, Barcelona, Spain \\ ${ }^{3}$ Department of Cell Biology, School of Medicine, University of Barcelona, Instituto de Investigaciones Biomédicas \\ August Pi Suñer, Barcelona, Spain
}

\begin{abstract}
This study addressed the contribution of acidic sphingomyelinase (ASMase) in TNF- $\alpha$-mediated hepatocellular apoptosis. Cultured hepatocytes depleted of mitochondrial glutathione (mGSH) became sensitive to TNF- $\alpha$, undergoing a time-dependent apoptotic cell death preceded by mitochondrial membrane depolarization, cytochrome $c$ release, and caspase activation. Cyclosporin $\mathrm{A}$ treatment rescued $\mathrm{mGSH}$-depleted hepatocytes from TNF- $\alpha$-induced cell death. In contrast, mGSHdepleted hepatocytes deficient in ASMase were resistant to TNF- $\alpha$-mediated cell death but sensitive to exogenous ASMase. Furthermore, although in vivo administration of TNF- $\alpha$ or LPS to galactosamine-pretreated $\mathrm{ASMase}^{+/+}$mice caused liver damage, $\mathrm{ASMase}^{-/-}$mice exhibited minimal hepatocellular injury. To analyze the requirement of ASMase, we assessed the effect of glucosylceramide synthetase inhibition on TNF- $\alpha$-mediated apoptosis. This approach, which blunted glycosphingolipid generation by TNF- $\alpha$, protected mGSH-depleted ASMase ${ }^{+/+}$hepatocytes from TNF- $\alpha$ despite enhancement of TNF- $\alpha$-stimulated ceramide formation. To further test the involvement of glycosphingolipids, we focused on ganglioside GD3 (GD3) because of its emerging role in apoptosis through interaction with mitochondria. Analysis of the cellular redistribution of GD3 by laser scanning confocal microscopy revealed the targeting of GD3 to mitochondria in $\mathrm{ASMase}^{+/+}$but not in $A S M a s e^{-/-}$hepatocytes. However, treatment of $A S M a s e^{-/-}$hepatocytes with exogenous ASMase induced the colocalization of GD3 and mitochondria. Thus, ASMase contributes to TNF- $\alpha$-induced hepatocellular apoptosis by promoting the mitochondrial targeting of glycosphingolipids.
\end{abstract}

J. Clin. Invest. 111:197-208 (2003). doi:10.1172/JCI200316010.

\section{Introduction}

TNF- $\alpha$ is a pleiotropic cytokine that in addition to its role in infection and immunity induces apoptosis in many cell types. The cellular signaling network used by TNF- $\alpha$ to cause apoptosis is complex and involves a variety of intermediates and protein-protein interactions

Received for publication May 28, 2002, and accepted in revised form November 26, 2002.

Address correspondence to: José C. Fernández-Checa, Liver Unit, Hospital Clinic i Provincial, Villarroel, 170, 08036-Barcelona, Spain. Phone: 34-93-227-5709; Fax: 34-93-451-5272;

E-mail: checa229@yahoo.com.

Carmen García-Ruiz and Anna Colell contributed equally to this work.

Conflict of interest: The authors have declared that no conflict of interest exists.

Nonstandard abbreviations used: acidic sphingomyelinase (ASMase); mitochondrial glutathione (mGSH); ganglioside GD3 (GD3); sphingolmyelinases (SMases); neutral SMase (NSMase); acidic SMase (ASMase); factor associated with NSMase activation (FAN); (R,S)-3-hydroxy-4-pentenoate (HP); 2'-7'-

dichlorofuorescein diacetate (DCFDA); tetramethylrhodamine methylester (TMRM); alanine aminotransferase (ALT); mitochondrial permeability transition (MPT); d-threo-1-phenyl-2decanoylamino-3-morpholino-propanol $\mathrm{HCl}$ (d-threo-PDMP); reactive oxygen species (ROS).
(1-4). In hepatocytes as in other type II cells, mitochondria play a pivotal role in apoptosis, and TNF- $\alpha-$ mediated hepatocellular apoptosis contributes to many forms of liver injury (3-8). The specific interaction of proapoptotic proteins - including Bcl-2 family members, signaling enzymes, transcription factors, or viral-encoded proteins - with mitochondrial components stimulates the release of mitochondrial factors that set in motion apoptotic pathways leading to the demise of the cell $(3,5-7,9,10)$. The mitochondrial downstream process that activates the caspases responsible for cell death involves the interaction of cytochrome $c$ with apaf-1, resulting in the proteolytic activation of procaspase 9 , which then triggers caspase 3 activation $(11,12)$. In addition, mitochondria can also regulate cell death by releasing several other proapoptotic factors, including caspases, the apoptosis-inducing factor, and Smac/Diablo (13-16).

Sphingolipids - in particular, ceramide - have emerged as putative signaling lipid intermediates that play a role in the stress response and cell death (17). The production of ceramide can occur by de novo synthesis through activation of serine-palmitoyl transferase, the rate-limiting enzyme in ceramide synthesis, 
or ceramide synthetase (17-19). Ceramide can also arise from hydrolysis of sphingomyelin-engaging sphingolmyelinases (SMases) (20). TNF- $\alpha$ binding to its plasma membrane receptor results in the activation of two major known types of SMases. The first, neutral SMase (NSMase), with an optimum $\mathrm{pH}$ of approximately 7.5, is membrane bound and $\mathrm{Mg}^{2+}$ dependent. The second, acidic SMase (ASMase), with an optimum $\mathrm{pH}$ of approximately 4.8 , is further subclassified into two isoforms, an endosomal/lysosomal ASMase and a secretory $\mathrm{Zn}^{2+}$-dependent ASMase (21-24). These enzymes are responsible for the ability of TNF- $\alpha$ to generate ceramide with various kinetics and, most importantly, at different intracellular locations $(17,23)$.

The role of individual SMases in apoptosis is controversial and not well established, and their engagement in apoptotic pathways depends on several conditions, such as the kind of apoptotic stimuli used and the cell type studied. For instance, NSMase has been shown to play a role in chemotherapy-mediated cell death (25). Furthermore, the ability of NSMase to signal apoptosis depends on the site within the plasma membrane where ceramide is released (26). Moreover, the factor associated with NSMase activation (FAN), an adaptor protein essential for NSMase activation, has been shown to contribute to TNF- $\alpha$-mediated fibroblast apoptosis (27). On the other hand, the deficiency in ASMase has been reported to impair oocyte maturation and apoptosis caused by ionizing radiation $(28,29)$. In addition, while overexpression of acid ceramidase, which diminishes ceramide production by ASMase, protects L929 cells from TNF- $\alpha$ (30), inhibition of ASMase early but not late during TNF- $\alpha$ signaling protects ML-1a cells against TNF- $\alpha$ (31). Finally, although some reports have indicated a role for ASMase in Fasmediated apoptosis (32-35), others have not (36), thus establishing a conundrum whether or not ASMase plays a role in Fas-mediated cell death.

In addition to its involvement in apoptotic signaling, ceramide also provides the carbon source for glycosphingolipid synthesis in the Golgi network. Ganglioside GD3 (GD3), a sialic acid-containing glycosphingolipid, has been identified as a lipid death effector because of its ability to interact and recruit mitochondria to apoptotic pathways, contributing to the mitochondrial-dependent apoptosome activation triggered by death ligands (37-42). On the other hand, it has been shown that prevention of glycolipid synthesis enhances apoptosis, reversing multidrug resistance in cancer cells $(43,44)$.

Information on signaling of hepatocellular apoptosis by TNF- $\alpha$ may be of therapeutic relevance for the treatment of liver diseases. Although several intermediates have been described to contribute to TNF- $\alpha-$ induced hepatocellular cell death - including FAN (27), cathepsin B (45) or Bid, a BH3-only member of the Bcl-2 family (46) - the role of ASMase in TNF- $\alpha-$ mediated apoptosis in hepatocytes has not been previously reported. Thus, the aims of the present study were to determine the role of ASMase in TNF- $\alpha$-mediated hepatocellular cell death and to estimate the relative contribution of ceramide versus glycosphingolipids in this process.

\section{Methods}

ASMase knockout mice and hepatocyte isolation. ASMase knockout mice (ASMase ${ }^{-/-}$), maintained in C57BL/6 background (kindly provided by E. Gulbins and R. Kolesnick), were propagated using heterozygous breeding pairs and genotyped by polymerase chain reaction of tail DNA as described previously $(35,47)$. Primers $5{ }^{\prime}$ AGCCGTGTCCTCTTCCTTAC- $3^{\prime}$ and 5'-CGAGACTGTTGCCAGACATC- $3^{\prime}$ were used to amplify a 269-bp product that is specific for exon 2 of the wild-type ASMase gene in conditions that have been described previously (33). Hepatocytes from male mice (8-12 weeks old) were prepared by collagenase perfusion with a flow rate of 7-9 $\mathrm{ml}$ per minute. Hepatocytes were cultured on rat-tail collagen-coated dishes as indicated for rat hepatocytes $(48,49)$.

Cell culture, incubations, and antibodies. Rat or mouse hepatocytes were incubated with recombinant human TNF- $\alpha(15-280 \mathrm{ng} / \mathrm{ml}$; Promega, Madison, Wisconsin, USA) or human placental ASMase (in 50\% glycerol, 25 $\mathrm{mM}$ potassium phosphate [ $\mathrm{pH} 4.5], 0.1 \%$ Triton $\mathrm{X}-100$, and $0.05 \mathrm{mM}$ phenylmethylsulfonylfluoride; Sigma Chemical Co., Madrid, Spain) as described previously (49). Mouse anti-GD3 monoclonal antibody, clone R24, produced by Matreya (Pleasant Gap, Pennsylvania, USA) as described originally (41), displays a specificity toward GD3 characterized previously in detail by compositional, partial structural analyses, immunostaining in thin-layer chromatography plates, and immunoelectron microscopy $(34,41,50)$. The human anti-mitochondrial antibodies, a gift from A. Serrano (CNB, CSIC, Madrid, Spain), recognize the E2 polypeptide of the mammalian mitochondrial pyruvate dehydrogenase complex $(51,52)$.

Selective depletion of mitochondrial GSH. (R,S)-3-hydroxy4-pentenoate (HP) was synthesized as described previously (53) and used to selectively deplete hepatocellular mitochondrial glutathione (mGSH) levels (54). Hepatocytes were incubated with $1 \mathrm{mM}$ HP for 5 minutes and then washed and fractionated into cytosol and mitochondria by Percoll centrifugation (54). GSH levels were determined in each fraction by high-performance liquid chromatography (48).

Determination of reactive oxygen species and mitochondrial membrane potential by flow cytometry. Hydrogen peroxide and mitochondrial membrane potential were determined using $2^{\prime}-7^{\prime}$-dichlorofuorescein diacetate (DCFDA) and tetramethylrhodamine methylester (TMRM; Molecular Probes, Eugene, Oregon, USA), respectively, in a FACStar flow cytometer (Becton Dickinson, San Jose, California, USA) as described previously $(40,55)$.

Cytochrome c release. The release of cytochrome $c$ from mitochondria after TNF- $\alpha$ exposure with or without HP preincubation was analyzed upon permeabilization 
of the plasma membrane of hepatocytes with digitonin $(80 \mu \mathrm{g} / \mathrm{ml})$ in permeabilization buffer $(210 \mathrm{mM}$ mannitol, $70 \mathrm{mM}$ sucrose, $5 \mathrm{mM}$ succinate, $0.2 \mathrm{mM}$ EGTA, 0.15\% BSA, $10 \mathrm{mM}$ HEPES [pH 7.2]). Cell plates were shaken at $4^{\circ} \mathrm{C}$ for 5 minutes, after which the permeabilization buffer was removed, and cells were centrifuged at $13,000 \mathrm{~g}$ for $10 \mathrm{~min}$. The presence of cytochrome $c$ and cytochrome $c$ oxidase was analyzed by immunoblotting as described previously (40) using anti-cytochrome $c$ antibody (clone 7H8.2C12; PharMingen, San Diego, California, USA) or mouse monoclonal anti-cytochrome $c$ oxidase (subunit IV; Molecular Probes).

Caspase processing and activation. The activation of caspase 3 in hepatocytes treated with TNF- $\alpha$ was determined as described previously (49) using a polyclonal anti-caspase 3 antibody (Santa Cruz Biotechnology, Santa Cruz, California, USA) after enhanced chemiluminescence detection. Caspase activity was determined by release of 7-amino-4-trifluoromethyl coumarin from Ac-DEVD-AMC (Bachem, Budendorf, Switzerland), and fluorescence was continuously recorded with emission at $460 \mathrm{~nm}$ and excitation at $355 \mathrm{~nm}$.

In vivo liver damage. C57BL6 mice were used at the age of 8-10 weeks $(25-30 \mathrm{~g})$. A single dose of recombinant murine TNF- $\alpha(10 \mathrm{mg} / \mathrm{kg}$ intravenously; Peprotech, London, United Kingdom) or LPS (50 $\mu \mathrm{g} / \mathrm{kg}$ intraperitoneally; Escherichia coli serotype 0128:B12; SigmaAldrich, St. Louis, Missouri, USA) in a total volume of $150 \mu \mathrm{l}$ of pyrogen-free saline containing $0.1 \%$ human serum was injected 10 minutes after intraperitoneal administration of galactosamine $(700 \mathrm{mg} / \mathrm{kg})$ in $200 \mu \mathrm{l}$ of pyrogen-free saline. Samples were taken at 2 and 4 hours after the challenge at the moment when the condition of the animals began to deteriorate $(56,57)$. Serum alanine aminotransferase (ALT) level was determined by a colorimetric test (Sigma-Aldrich). For histology, liver specimens were washed with PBS and paraffin embedded. Sections of $7 \mu \mathrm{m}$ were made and stained with hematoxylin and eosin using standard methods.

Inactivation of ASMase. ASMase from rat hepatocytes was inactivated before treatment with TNF- $\alpha$ by prior incubation of cells with imipramine $(50 \mu \mathrm{M})(58,59)$. ASMase activity in cellular extracts was determined by monitoring $\mathrm{N}$-methyl- $\left[{ }^{14} \mathrm{C}\right]$ sphingomyelin $(56.6 \mathrm{mCi} /$ $\mathrm{mmol}$ ) hydrolysis as described previously (49).

Measurement of GD3 and ceramide levels. Ganglioside (including GM1 and GD3) levels in hepatocytes $\left(3-4 \times 10^{6}\right)$ were determined by high-performance thin-layer chromatography as described previously (40). Ceramide levels were quantified by high-performance liquid chromatography (49).

Assessment of cell death. To determine the incidence of cell death in hepatocytes treated with TNF- $\alpha$, cell cultures were doubly stained with propidium iodide and Hoechst 33258. Propidium iodide is a vital nucleic acid-staining dye that penetrates cells with compromised plasma membrane (necrotic cells). Morphological changes in the nuclei of cells undergoing apoptotic cell death were determined by staining with the DNAbinding fluorochrome Hoechst 33258. Apoptotic nuclear changes include condensation, margination, and segmentation of the nuclei into several fragments. After TNF- $\alpha$ incubation with or without HP pretreatment, cells were stained with both dyes $(10 \mu \mathrm{M}$ final concentration) for $10-15$ minutes at $37^{\circ} \mathrm{C}$. Afterwards, cells were fixed with paraformaldehyde and mounted on a fluorescence microscope. Quantitation of apoptotic and necrotic cells was performed by counting at least 250 cells in six different high-power fields and was expressed as a percentage of total cells counted.

NF- $K B$ activation and translocation of Bax to mitochondria. NF-кB DNA binding activity in nuclear extracts was assessed by electrophoretic mobility shift assays using an NF- $\mathrm{KB}$ consensus oligonucleotide (5'-AGTTGAGGGGACTTTCCCAGGC-3') as described previously (42). Supershift assays were conducted by using the antibodies anti-RelA, p50, and p52 as described (42). The mitochondrial translocation of Bax was assessed by Western blot analyses of mitochondria prepared from cultured mouse hepatocytes upon incubation with TNF- $\alpha$ as described previously (60). Cells $\left(2-3 \times 10^{6}\right)$ were collected, washed twice with PBS, and resuspended in $500 \mu \mathrm{l}$ of isolation buffer $(200 \mathrm{mM}$ mannitol, $70 \mathrm{mM}$ sucrose, $10 \mathrm{mM}$ HEPES-KOH, $1 \mathrm{mM}$ EGTA, $0.2 \%$ BSA [pH 7.5]) supplemented with a protease inhibitor cocktail (Roche, Manheim, Germany). After chilling on ice for 10 minutes, cells were disrupted by 20 passages through a $25 \mathrm{G}$ syringe. The homogenate was centrifuged at $4^{\circ} \mathrm{C}$ for 10 minutes at $600 \mathrm{~g}$, and the supernatant obtained was centrifuged at $10,000 \mathrm{~g}$ for 10 minutes. The mitochondrial pellet was resuspended in $250 \mathrm{mM}$ sucrose, $10 \mathrm{mM}$ HEPES- $\mathrm{KOH}, 1$ $\mathrm{mM}$ ATP, $0.08 \mathrm{mM} \mathrm{ADP}$, and $2 \mathrm{mM} \mathrm{K}_{2} \mathrm{HPO}_{4}(\mathrm{pH} 7.5)$. Mouse hepatocytes were treated with TNF- $\alpha(0.28$ $\mu \mathrm{g} / \mathrm{ml})$ plus galactosamine $(1 \mathrm{mM})$ for 16 hours. Western blots (40 $\mu \mathrm{g}$ of protein per lane) were performed using Bax mouse monoclonal antibody (SC-7480, 1:200; Santa Cruz Biotechnology) and developed as described above for cytochrome $c$.

Immunocytochemical staining. Mouse hepatocytes were fixed for 10 minutes in 3.7\% paraformaldehyde in 0.1 $\mathrm{M}$ phosphate buffer before permeabilization with $0.1 \%$ saponin in $0.5 \%$ BSA/PBS buffer for 15 minutes. The immunolocalization of GD3 relative to mitochondria was performed as described before for rat hepatocytes (61) using mouse anti-GD3 antibody (1:500) and human anti-mitochondrial antibody (1:2000). Confocal images were collected using a Leica TCS-NT laser scanning confocal microscope equipped with an argon-krypton laser and a 63× Leitz Plan-Apo objective (numerical aperture, 1.4). The number of cells observed per field was at least 100 for each treatment.

Statistical analyses. Results are expressed as means \pm SD and are averages of three to five values per experiment and condition. Statistical analyses of mean values for multiple comparisons were made by one-way analysis of variance followed by Fisher's exact test. 
a
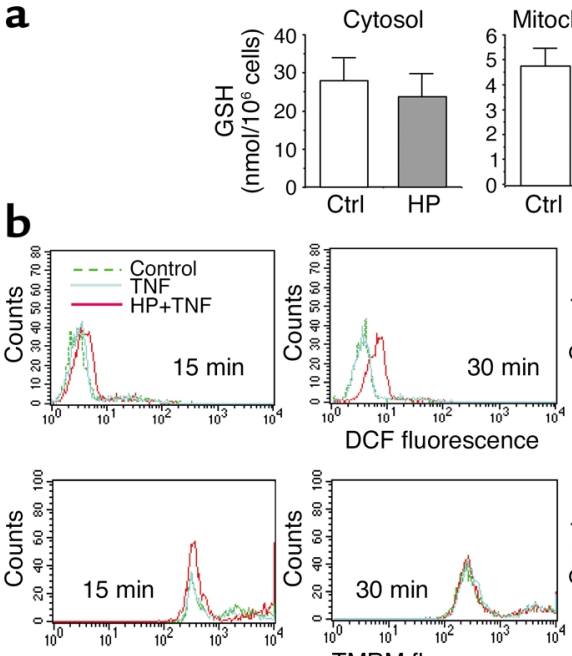

TMRM fluorescence
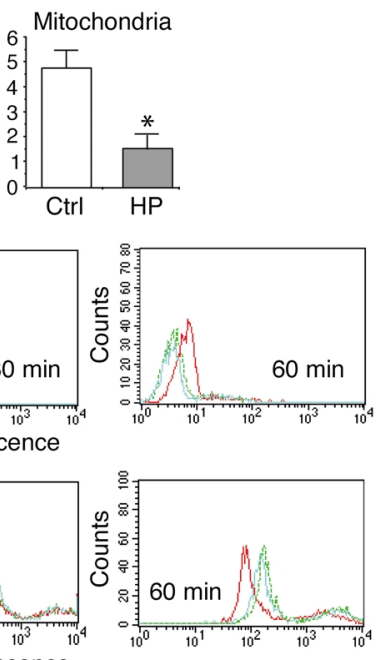

c

Cytochrome $c$

Cytochrome $c$ oxidase

d
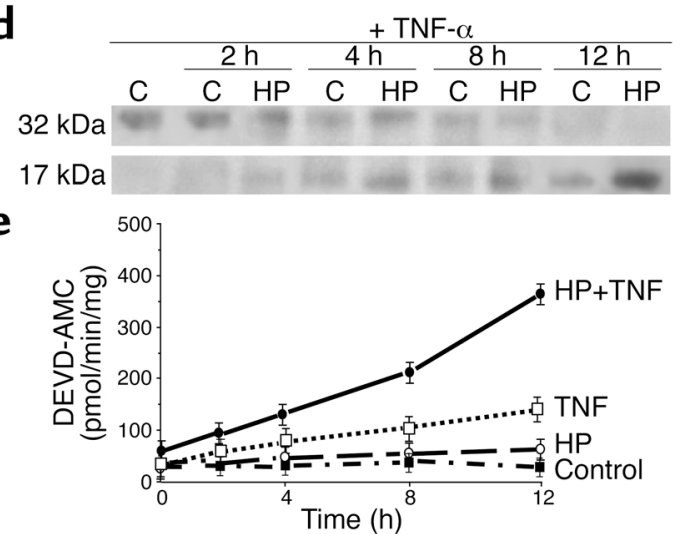

Figure 1

Mitochondrial GSH depletion facilitates TNF- $\alpha$-mediated mitochondrial depolarization. (a) Cultured rat hepatocytes were pretreated with HP $(1 \mathrm{mM})$ for 5 minutes and then fractionated to obtain cytosol and mitochondria for GSH determination by high-performance liquid chromatography. Results are expressed as means $\pm \mathrm{SD}(n=4$ or 5$)$. ${ }^{*} P<0.05$ versus control. (b) After HP treatment, hepatocytes were then exposed to TNF- $\alpha(280 \mathrm{ng} / \mathrm{ml})$ for 15-60 minutes. Peroxide formation and mitochondrial membrane potential were determined upon staining of cells with DFCDA and TMRM, respectively, and fluorescence of both fluorochromes was determined by flow cytometry. A representative profile of four independent experiments is shown. (c) Hepatocytes treated with TNF- $\alpha(280 \mathrm{ng} / \mathrm{ml})$ over time with or without HP pretreatment were permeabilized with digitonin, and cell extracts were analyzed for cytochrome $c$ or cytochrome $c$ oxidase as indicated in the Methods. (d and $\mathbf{e}$ ) Aliquots of cell extracts were used for the detection of active caspase 3 fragments by immunoblotting (d) or activity determination using a fluorescent peptide (e). Results are expressed as means \pm SD ( $n=3$ or 4 independent experiments).

\section{Results}

Selective $m G S H$ depletion sensitizes hepatocytes to TNF- $\alpha$. Hepatocytes are known to be resistant to TNF- $\alpha$. Blocking protein or total RNA synthesis or NF-kB activation has been commonly used to unmask the ability of TNF- $\alpha$ to induce hepatocellular apoptosis $(4,8)$. We have used HP to generate a Michael acceptor within mitochondria as a strategy to selectively deplete the mGSH $(53,54)$. These mGSH-depleted hepatocytes were then challenged with TNF- $\alpha$ $(28-280 \mathrm{ng} / \mathrm{ml})$. HP caused a dramatic and selective mGSH depletion but spared cytosolic GSH in rat hepatocytes (Figure 1a). This approach by itself did not impair mitochondrial function, as shown by maintenance of mitochondrial membrane potential estimated from TMRM fluorescence by flow cytometry. However, when mGSH-depleted hepatocytes were exposed to TNF- $\alpha(280 \mathrm{ng} / \mathrm{ml})$, there was a significant and early generation of peroxides that preceded the loss of mitochondrial membrane potential (Figure $1 b)$, indicating the onset of mitochondrial permeability transition (MPT). Since one of the critical components of apoptotic pathways is the release of cytochrome $c$ from mitochondria, we next characterized the kinetics of this event in hepatocytes after TNF- $\alpha$ exposure and the effect of HP preincubation. The release of cytochrome $c$ was detectable after 2 hours of incubation with TNF- $\alpha$ only in hepatocytes that were pretreated with HP (Figure 1c). Furthermore, this event preceded the activation of caspase 3 as assessed by the time-dependent increase of active caspase 3 fragments (Figure 1d) and activity determined from the fluorescence of AMC released from the synthetic peptide DEVD-AMC (Figure 1e).

Previous studies have shown that various strategies - for example, cycloheximide, galactosamine, or acetaminophen - rendered hepatocytes sensitive to TNF- $\alpha$ exposure which induced apoptotic and necrotic cell death (62-64). To determine the extent of cell death induced by TNF- $\alpha$ under these conditions, cell cultures were labeled with propidium iodide, a vital stain, and the permeable DNA-binding fluorochrome Hoechst 33258. HP pretreatment sensitized hepatocytes to TNF- $\alpha$ exposure with increasing incidence of both apoptosis and necrosis (Figure 2a). Although apoptosis increased gradually during the initial 8 hours of incubation with TNF- $\alpha$ (declining thereafter), necrosis increased continually over time. By 8 hours after TNF- $\alpha$ incubation, the magnitude of apoptosis and necrosis was comparable and seen only in HP-pretreated cells (Figure 2a). Consistent with the critical role of MPT in TNF- $\alpha$-mediated cell death (8), cyclosporin A treatment protected HP-exposed hepatocytes from TNF- $\alpha$ (Figure 2a). The sensitivity of mGSH-depleted hepatocytes to TNF- $\alpha$ was also observed at lower doses of TNF- $\alpha$. HP-pretreated hepatocytes underwent a time-dependent cell death after incubation with $25 \mathrm{ng} / \mathrm{ml}$ of TNF- $\alpha$ (Figure 2a). Similar findings of cell death were observed when hepatocytes were sensitized to TNF- $\alpha$ by actinomycin 
a

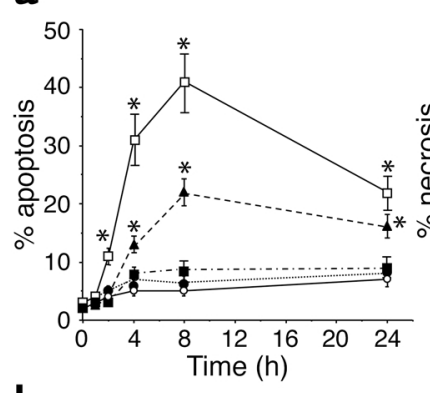

b
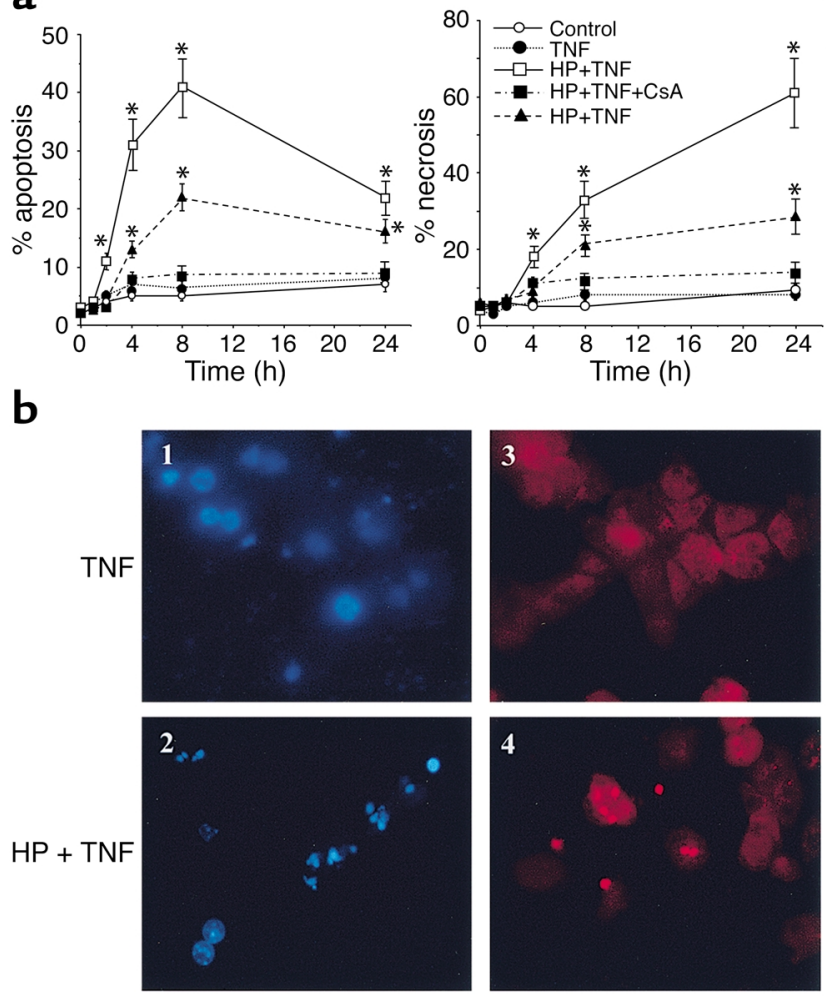

D preincubation in agreement with previous reports (45). These findings indicate that the selective depletion of mGSH sensitizes hepatocytes to TNF- $\alpha$ by facilitating the onset of MPT.

Inhibition of ASMase activity protects sensitized hepatocytes from TNF- $\alpha$. To examine the role of ASMase in TNF- $\alpha$-mediated hepatocellular apoptosis, we analyzed the effects of ASMase inactivation on the survival of mGSH-sensitized hepatocytes after TNF- $\alpha$ treatment. The activity of ASMase in response to

\section{Figure 3}

Imipramine inactivates ASMase in hepatocytes. (a) Hepatocytes were treated with TNF- $\alpha(280 \mathrm{ng} / \mathrm{ml})$ for 2 hours with or without preincubation with imipramine $(50 \mu \mathrm{M})$. Cellular extracts were used for ASMase activity determined from $\mathrm{N}$-methyl- $\left[{ }^{14} \mathrm{C}\right]$ sphingomyelin $(56.6 \mathrm{mCi} / \mathrm{mmol})$ hydrolysis. Levels of phosphorylcholine produced from sphingomyelin were determined in the aqueous phase by scintillation counting. Results are expressed as means \pm SD $(n=5$ independent experiments). ${ }^{*} P<0.05$ versus control, and ${ }^{*} P<0.05$ versus TNF- $\alpha$. (b) The activity of ASMase with or without imipramine pretreatment was determined at different times after TNF- $\alpha$ exposure as in a. (c) To test the role of imipramine in cell survival, hepatocytes were first treated with HP and then incubated with TNF- $\alpha$ $(280 \mathrm{ng} / \mathrm{ml})$ for 12 hours. Cell death was determined by Hoechst 33258 and propidium iodide staining. Results are expressed as means $\pm \mathrm{SD}\left(n=4\right.$ independent experiments). ${ }^{*} P<0.05$ versus control, and ${ }^{*} P<0.05$ versus HP plus TNF- $\alpha$. (d) The activity of caspase 3 was determined under these various conditions with or without imipramine preincubation from the fluorescence of released AMC fragments. Results are expressed as means \pm SD $(n=4$ independent experiments). ${ }^{*} P<0.05$ versus control, and ${ }^{*} P<0.05$ versus HP plus TNF- $\alpha$.

\section{Figure 2}

Mitochondrial GSH depletion sensitizes hepatocytes to TNF- $\alpha$. (a) Cultured hepatocytes were exposed to TNF- $\alpha(280 \mathrm{ng} / \mathrm{ml}$, solid line; $25 \mathrm{ng} / \mathrm{ml}$, dashed line) for various periods of time with or without HP preincubation to deplete the mGSH levels. Cell death was determined by double staining with Hoechst 33258 and propidium iodide to detect apoptotic and necrotic cells, respectively. At least 250 cells in six different high-power fields were counted and expressed as a percentage of total cells (please note the scale difference). HP alone did not affect cell survival. Results are expressed as means \pm SD ( $n=4$ experiments). ${ }^{*} P<0.05$ versus control. (b) Representative fluorescent micrographs of control hepatocytes exposed to TNF- $\alpha$ (panels 1 and 3) or HP-pretreated hepatocytes (panels 2 and 4). Blue fragmented nuclei (panel 2) represent apoptotic cells, whereas red nuclei (panel 4) are indicative of necrotic cells.

TNF- $\alpha$ increased twofold as compared with control hepatocytes, an effect that was observed within 10-20 minutes after TNF- $\alpha$ incubation (Figure 3 , a and b). The pretreatment of hepatocytes with HP did not modify the activity of ASMase in response to TNF- $\alpha$ (data not shown). ASMase has been shown to be processed from its precursor form $(75 \mathrm{kDa})$ to the active $72 \mathrm{kDa}$ ASMase form (65). Imipramine, a tricyclic antidepressant, induces the proteolysis of the active $72 \mathrm{kDa}$ ASMase form $(58,59)$, and hence it is expected to inhibit the stimulated ASMase activity, as shown previously $(59,66)$. Hepatocytes were preincubated with imipramine before exposure to TNF- $\alpha$, attenuating the ASMase activity induced by TNF- $\alpha$ (Figure 3a). To test the role of imipramine on cell survival, hepatocytes were first treated with $\mathrm{HP}$ and then exposed to TNF- $\alpha$. Although HP-pretreated hepatocytes were sensitive to TNF- $\alpha$-induced apoptosis, imipramine pretreatment protected HP-sensitized hepatocytes against TNF- $\alpha$ exposure (Figure $3 c$ ). This protective effect of imipramine was accompanied by a decrease in the activation of caspase 3 (Figure 3d).
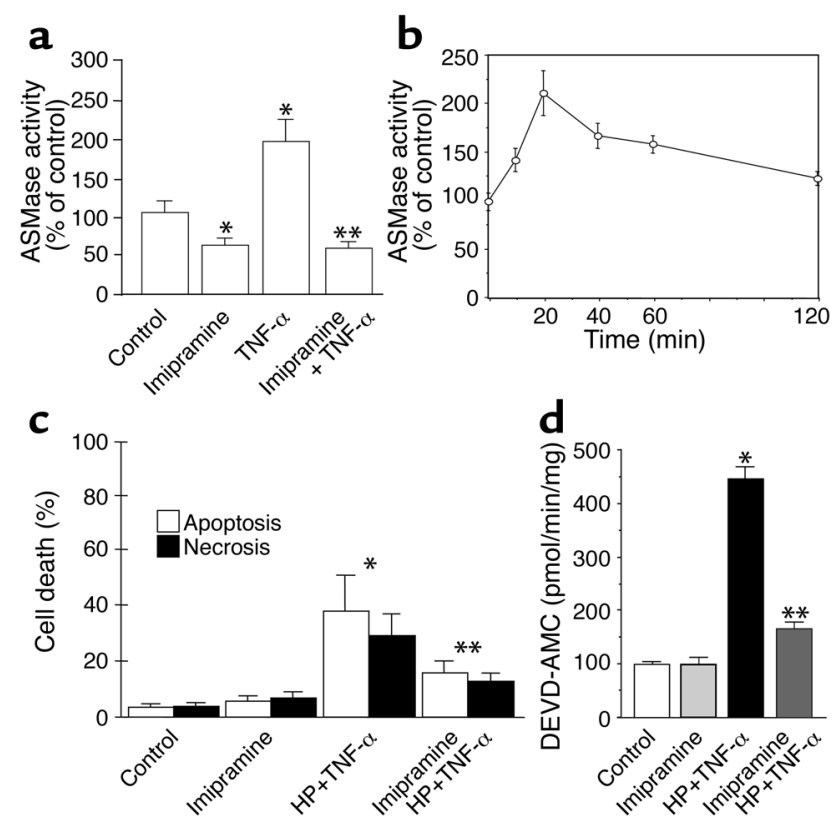

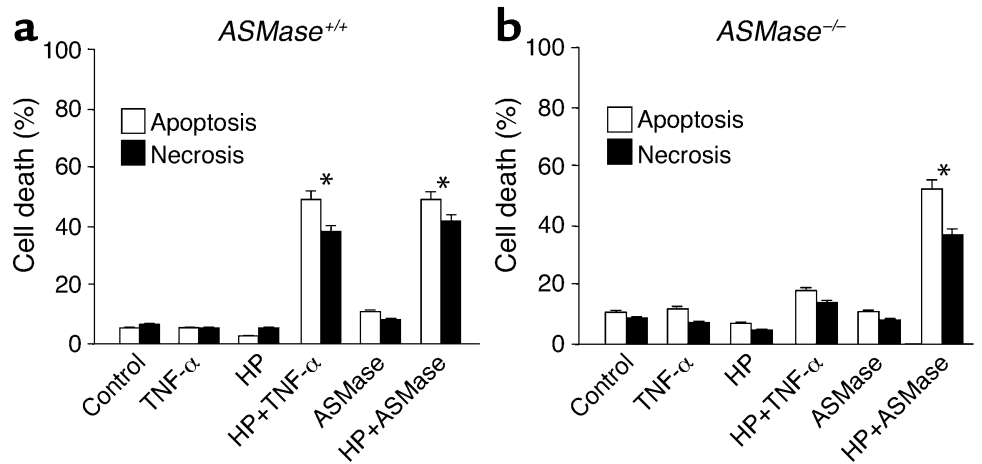

\section{Figure 4}

Resistance of hepatocytes from ASMase knockout mice to TNF- $\alpha$-induced apoptosis. $\operatorname{ASMase}^{+/+}(\mathbf{a})$ or $\mathrm{ASMase}^{-/-}$(b) mouse hepatocytes were first pretreated with HP to deplete the $\mathrm{mGSH}$ pool and then treated with either TNF- $\alpha(280 \mathrm{ng} / \mathrm{ml})$ or ASMase $(0.4$ $\mathrm{U} / \mathrm{ml}$ ) for 12 hours. Cell death was determined by Hoechst 33258 and propidium iodide staining. Results are expressed as means \pm SD $(n=5$ independent experiments). ${ }^{*} P<0.05$ versus control.
Thus, these findings reveal that ASMase contributes to TNF- $\alpha$ apoptosis in sensitized hepatocytes and that prevention of stimulated ASMase activity protects hepatocytes from TNF- $\alpha$-induced cell death.

ASMase-deficient hepatocytes are resistant to TNF- $\alpha-$ induced cell death. In order to establish the role of ASMase in TNF- $\alpha$-mediated apoptosis in a more definitive fashion, we used hepatocytes from ASMase $^{+/+}$and ASMase ${ }^{-/-}$mice. Treatment of mouse hepatocytes with HP resulted in selective depletion of mGSH levels by $68 \% \pm 6 \%(P<0.05)$ without affecting the cytosolic pool of GSH $(88 \% \pm 8 \%$ of control hepatocytes). Under these conditions, and similar to the outcome seen with rat hepatocytes, HP pretreatment sensitized mouse hepatocytes to TNF- $\alpha$-induced apoptotic and necrotic cell death (Figure 4a). Cyclosporin A pretreatment protected HP-treated ASMase $^{+/+}$hepatocytes against TNF- $\alpha$-mediated cell death (data not shown). Furthermore, HP pretreatment sensitized hepatocytes to human placental ASMase (Figure 4a). Monensin pretreatment prevented TNF- $\alpha$ or exogenous human placental ASMase-induced apoptosis in HP-pretreated mouse hepatocytes (data not shown).

In contrast with these findings, ASMase ${ }^{-/-}$hepatocytes were resistant to TNF- $\alpha$ exposure, despite HP pretreatment (Figure 4b). The levels of GSH in the mitochondrial fraction after HP exposure were depleted down to $26 \% \pm 8 \%$ of those of control hepatocytes, with the sparing of cytosolic GSH. Despite the
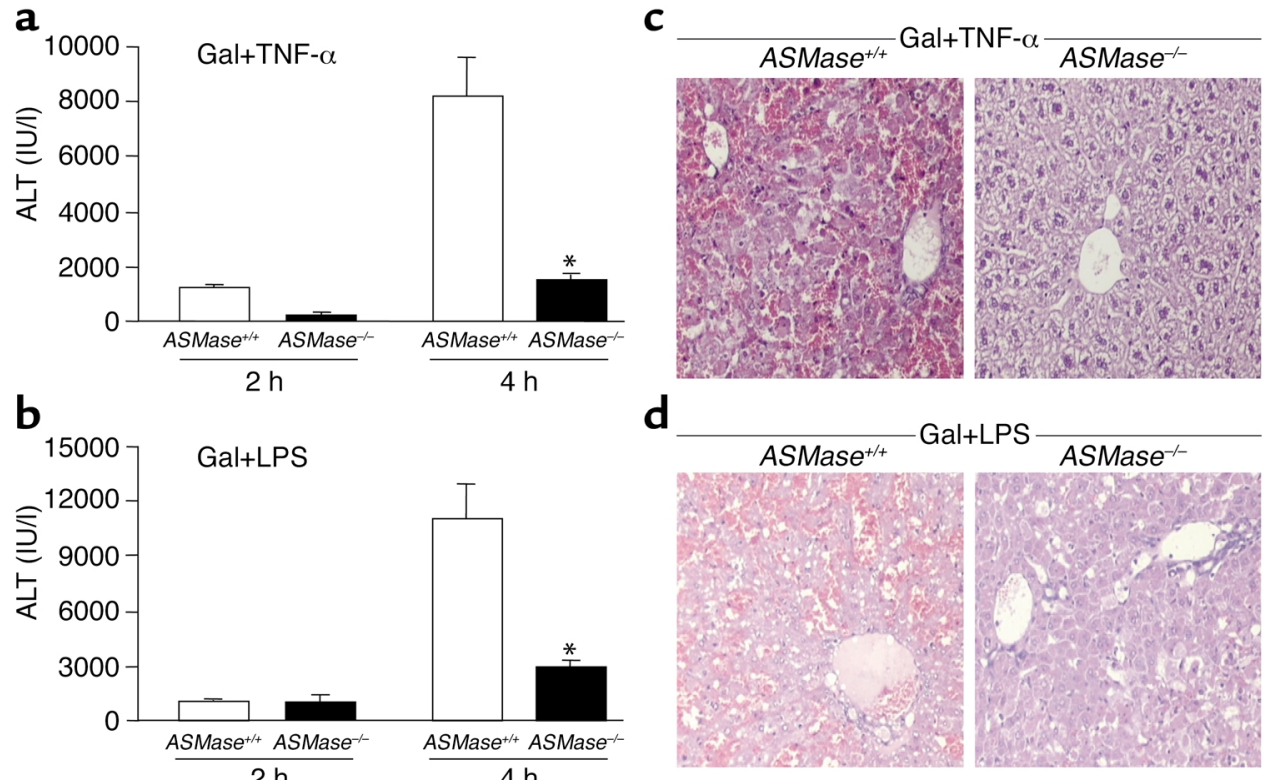

\section{Figure 5}

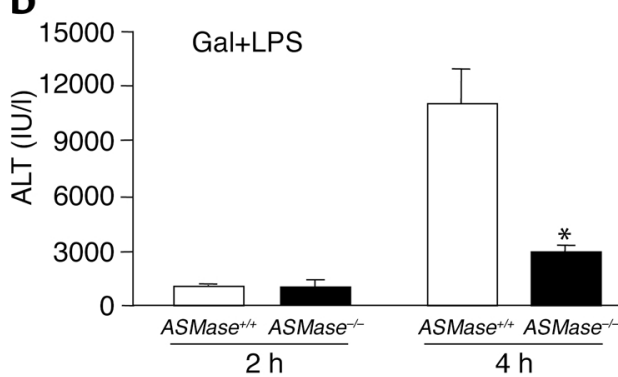

In vivo TNF- $\alpha$-induced liver damage in ASMase knockout mice. (a) ASMase ${ }^{+/+}$and ASMase ${ }^{-/-}$mice were first administered galactosamine (700 $\mathrm{mg} / \mathrm{kg}) 10$ minutes before the intravenous injection of TNF- $\alpha(10 \mathrm{mg} / \mathrm{kg})$ or saline (controls). At 2 and 4 hours, mice were sacrificed, and blood was drawn to determine ALT concentrations. ALT concentrations in control samples were less than $20 \mathrm{IU} / \mathrm{ml}$. Results are expressed as means $\pm \mathrm{SD}\left(n=5\right.$ independent experiments). ${ }^{*} P<0.05$ versus ASMase ${ }^{+/+}$. (b) Serum ALT levels were determined as in (a), except that mice were injected with LPS $(50 \mu \mathrm{g} / \mathrm{kg})$ after galactosamine pretreatment. Results are expressed as means \pm SD $(n=5$ independent experiments). ${ }^{*} P<0.05$ versus $A S M a s e^{+/+}$. (c) Representative hematoxylin and eosin staining of ASMase $^{+/+}$and $A S M a s e^{-/-}$mouse liver specimens harvested 4 hours after administration of TNF- $\alpha$ plus galactosamine. (d) Representative hematoxylin and eosin staining of $A S M a s e^{+/+}$and $A S M a s e^{-/-}$mouse liver specimens harvested 4 hours after administration of LPS plus galactosamine. 
resistance of $A S M a e^{-/-}$hepatocytes to TNF- $\alpha$, these cells were susceptible to exogenous human placental ASMase exposure (Figure 4b). Addition of exogenous ASMase induced cytochrome $c$ release and caspase 3 activation in both $\mathrm{ASMase}^{+/+}$and $\mathrm{ASMase}^{-/-}$hepatocytes (data not shown). Moreover, ASMase ${ }^{+/+}$and ASMase $^{-/-}$hepatocytes were resistant to bacterial NSMase $(0.4-1.0 \mathrm{U} / \mathrm{ml})$ treatment with or without pretreatment with HP. Similar findings were observed when hepatocytes were sensitized with actinomycin D pretreatment (62 \pm 7 vs. $19 \pm 6$ apoptosis in ASMase $^{+/+}$ as compared with $A S M a e^{-/-}$cells, $\left.P<0.05\right)$, indicating that ASMase is involved after sensitization of hepatocytes by means other than mGSH depletion. Thus, taken together, these findings indicate that selective mGSH depletion sensitizes mouse hepatocytes to both TNF- $\alpha$ and exogenous ASMase.

Resistance of ASMase ${ }^{-/-}$mice to endogenous or exogenous TNF- $\alpha$-induced liver damage in vivo. To examine the role of ASMase in TNF- $\alpha$-mediated liver injury in vivo, $\mathrm{ASMase}^{+/+}$and $\mathrm{ASMase}^{-/-}$mice were sensitized by galactosamine treatment to endogenous TNF- $\alpha$ secretion or exposure to exogenous TNF- $\alpha(56,57)$. At 2 and 4 hours after TNF- $\alpha$ treatment, serum ALT concentrations were significantly higher in $\mathrm{ASMase}^{+/+}$ mice than in $\mathrm{ASMase}^{-/-}$mice $(1545 \pm 234 \mathrm{IU} / \mathrm{ml}$ vs. $257 \pm 67 \mathrm{IU} / \mathrm{ml}$ at 2 hours and $8157 \mathrm{IU} / \mathrm{ml} \pm 783$ vs. $1787 \pm 324 \mathrm{IU} / \mathrm{ml}$ at 4 hours) (Figure 5a). Livers from the $\mathrm{ASMase}^{+/+}$mice displayed extensive hemorrhagic lesions and clusters of damaged cells. In contrast, liver specimens from ASMase ${ }^{-/-}$mice showed minimal damage (Figure 5c). Further studies revealed that TNF- $\alpha$ killed $91 \%$ of mice at 5-6 hours after treatment $(n=5)$, whereas $85 \%$ of ASMase $^{-/-}$mice survived at least 48 hours after TNF- $\alpha$ treatment $(n=4)$. Similar findings were observed when mice were injected with a single dose of LPS to stimulate endogenous TNF- $\alpha$ secretion in terms of se-rum ALT levels and histological findings (Figure 5, b and d). Thus, these data clearly show that ASMase plays a key role in TNF- $\alpha-$ mediated liver damage.
Glycosphingolipids rather than ceramide contribute to TNF- $\alpha$-mediated hepatocellular apoptosis. The preceding data indicate that ASMase is required for efficient TNF- $\alpha$-induced hepatocellular apoptosis. Since ASMase generates ceramide - which, in turn, fuels glycosphingolipid formation - we next estimated the relative contribution of ceramides versus glycosphingolipids in TNF- $\alpha$-induced apoptosis. This question is of particular relevance since both types of lipids have been involved in apoptosis. To address this issue, the generation of ceramide and glycosphingolipids by TNF- $\alpha$ was determined with or without glucosylceramide synthase inhibition. Treatment of hepatocytes with TNF- $\alpha$ significantly increased the levels of ceramide $(296 \% \pm 34 \%$ of control levels, $P<0.05)$ and glycosphingolipids, including gangliosides GD3 and GM1 $(367 \% \pm 47 \%$ and $338 \% \pm 54 \%$ of control levels, respectively; $P<0.05$ ) (Figure 6 , a and b), at 2 hours after incubation, with the synthesis of GD3 being significantly higher than basal levels by 40-60 minutes after TNF- $\alpha$ incubation. Pretreatment of hepatocytes with d-threo-1phenyl-2-decanoylamino-3-morpholino-propanol $\mathrm{HCl}$

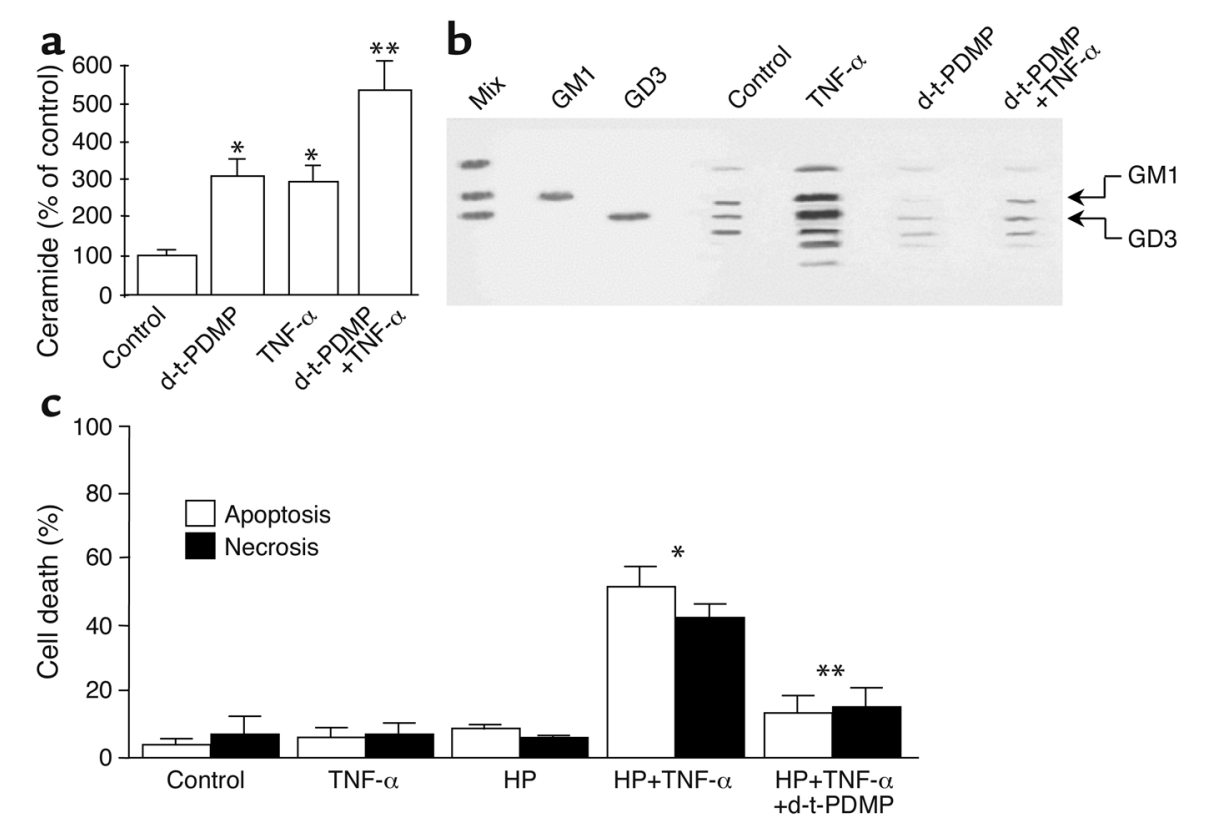

Figure 6

Effect of glucosylceramide synthetase inhibition on sphingolipids and hepatocellular survival. (a) Cultured hepatocytes were treated with TNF- $\alpha(280 \mathrm{ng} / \mathrm{ml})$ for 2 hours with or without d-threoPDMP (d-t-PDMP) pretreatment to inhibit glucosylceramide synthase. Cellular lipids were extracted by chloroform/methanol, and ceramide levels were determined by high-performance liquid chromatography. Results are expressed as means $\pm \mathrm{SD}\left(n=4\right.$ independent experiments). ${ }^{*} P<0.05$ versus control, and ${ }^{*} P<0.05$ versus HP plus TNF- $\alpha$. (b) Lipid extracts from hepatocytes treated with TNF- $\alpha$ with or without d-threo-PDMP were applied to high-performance thin-layer chromatography plates to resolve glycosphingolipids along with authentic ganglioside standards (GD3 and GM1). The level of GD3 was calculated by densitometric analyses of high-performance thin-layer chromatography plates and compared with a standard curve generated using known amounts of GD3. (c) To determine the role of glycosphingolipid synthesis inhibition on hepatocellular survival, cells were first treated with HP and then exposed to TNF- $\alpha$ for 12 hours with or without d-threo-PDMP pretreatment. Cell death was determined by Hoechst 33258 and propidium iodide staining after 12 hours of TNF- $\alpha$ incubation. Results are expressed as means \pm SD ( $n=6$ independent experiments). ${ }^{*} P<0.05$ versus control, and ${ }^{*} P<0.05$ versus HP plus TNF- $\alpha$. 

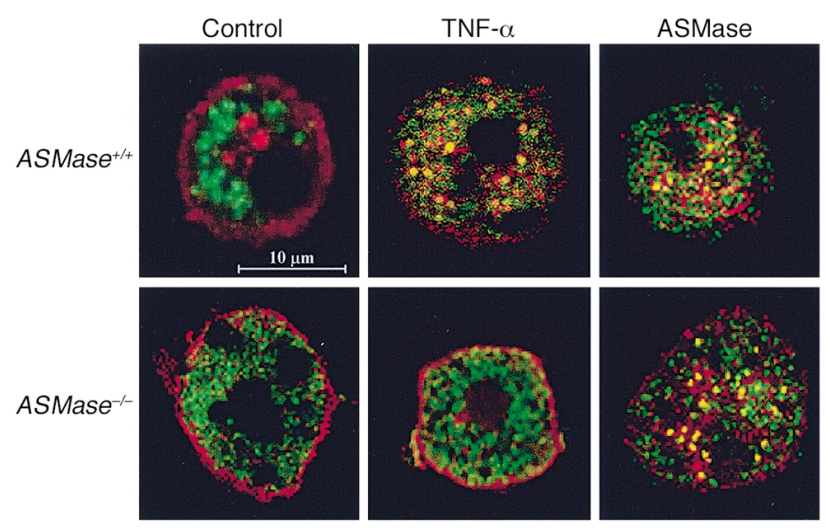

\section{Figure 7}

Immunocytochemical localization of GD3 and mitochondria in response to TNF- $\alpha$ and exogenous ASMase. ASMase ${ }^{+/+}$and $\mathrm{ASM}^{-/-}$ hepatocytes were incubated with TNF- $\alpha(280 \mathrm{ng} / \mathrm{ml})$, human placental ASMase $(0.4 \mathrm{U} / \mathrm{ml})$, or vehicle (control) for 4 hours and then doubled immunostained with anti-GD3 and anti-mitochondrial antibodies followed by appropriate secondary antibodies. Merged images of red (GD3) and green (mitochondria) fluorescence were collected by confocal microscopy. Colocalization of GD3 with mitochondria appears as yellow spots reflecting the merged red and green fluorescence. The bar represents $10 \mu \mathrm{m}$. At least 100 cells per condition were examined. Less than $10 \%$ of control cells displayed merged fluorescence, whereas colocalization was observed in more than $85 \%$ of the cells examined following TNF- $\alpha$. Representative images of four independent experiments with similar results are shown.

(d-threo-PDMP), an inhibitor of glucosylceramide synthase, abolished the stimulation of glycosphingolipid levels by TNF- $\alpha$, whereas it enhanced ceramide generation as compared with the stimulation induced by TNF- $\alpha$ itself (Figure 6, $a$ and $b$ ). The inactive isomer $d-$ erythro-PDMP did not have any effect (data not shown). In order to test the effect of d-threo-PDMP on hepatocyte survival, cells were first sensitized with HP treatment. The exposure of HP-treated hepatocytes to TNF- $\alpha$ increased the levels of ceramide and gangliosides to $245 \% \pm 34 \%$ and $324 \% \pm 54 \%$, respectively ( $P=0.05$ vs. percentage of unstimulated controls), in the absence of d-threo-PDMP and to $623 \% \pm 76 \%$ and $113 \% \pm 23 \%$, respectively, in the presence of d-threo-PDMP. The generation of ceramide and gangliosides by TNF- $\alpha$ was similar in the presence or absence of HP treatment. Despite the divergent TNF- $\alpha$-induced generation of ceramide and glycosphingolipids in the presence of d-threo-PDMP, this agent protected HP-treated hepatocytes against TNF- $\alpha$-induced apoptotic and necrotic cell death (Figure $6 c$ ). Similar findings were observed when glucosylceramide synthase was inhibited by N-butyldeoxynojirimycin (data not shown). Thus, these findings suggest the involvement of glycosphingolipids generated from ASMase-induced ceramide formation as key intermediates of TNF- $\alpha$-induced hepatocellular apoptosis.

TNF- $\alpha$ stimulates the targeting of ganglioside GD 3 to mitochondria. Out of the repertoire of glycosphingolipids synthesized from ceramide, we focused on GD3, since this glycosphingolipid has emerged as a proapoptotic lipid effector because of its interaction with mitochondria (38-42). To examine if GD3 is targeted to mitochondria during TNF- $\alpha$ signaling, we examined the localization of GD3 and mitochondria by confocal microscopy using an anti-GD3 antibody, whose specificity toward GD3 has been documented previously $(41,50)$, and an antimitochondrial antibody that recognizes the $\mathrm{E} 2$ polypeptide of the mammalian pyruvate dehydrogenase complex $(51,52)$. The merged fluorescence of both antibodies is shown in Figure 7. In control ASMase ${ }^{+/+}$mouse hepatocytes, most of the GD3 was present at the cell surface and in intracellular structures corresponding to the Golgi network as verified by the colocalization of GD3 with the asialoglycoprotein receptor, as shown recently in cultured rat hepatocytes (61). After TNF- $\alpha$ treatment, GD3 disappeared from the plasma membrane and was targeted to mitochondria, as estimated by the presence of merged red and green fluorescence (Figure 7). In contrast, TNF- $\alpha$ did not induce the mitochondrial targeting of GD3 in ASMase ${ }^{-/}$hepatocytes (Figure 7). These findings, therefore, correlate with the resistance of hepatocytes deficient in ASMase to TNF- $\alpha$-mediated cell death (Figure 4). Since these cells were sensitive to exogenous ASMase treatment, we examined the redistribution of GD3 in response to exogenous human placental ASMase. Both ASMase ${ }^{+/+}$and ASMase $e^{-/-}$hepatocytes showed the colocalization of GD3 with mitochondria (Figure 7), in agreement with previous results (61). Moreover, to test the role of ASMase in the cytotoxicity of GD3, ASMase ${ }^{+/+}$and ASMase - $^{-/}$were exposed to GD3 after HP pretreatment. As seen, both types of cells were equally sensitive to GD3 treatment, and this effect was
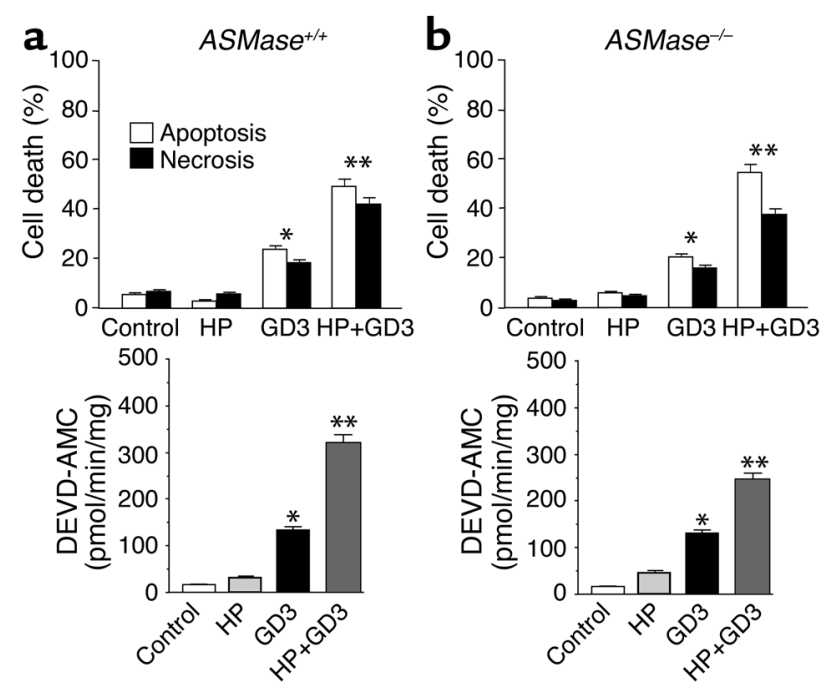

\section{Figure 8}

Cytotoxicity of GD3 in mouse hepatocytes. ASMase ${ }^{+/+}(\mathbf{a})$ and $\mathrm{ASM}^{-1-}$ (b) hepatocytes were treated with GD3 $(10 \mu \mathrm{M})$ with or without HP preincubation, and cell death was determined by Hoechst 33258 and propidium iodide staining to quantify apoptosis and necrosis after 8 hours. Caspase 3 activity was determined in cell extracts from the fluorescence of AMC fragments. Results are expressed as means \pm SD ( $n=4$ independent experiments). ${ }^{*} P<0.05$ versus control, and ** $P<0.05$ versus GD3 without HP preincubation. 


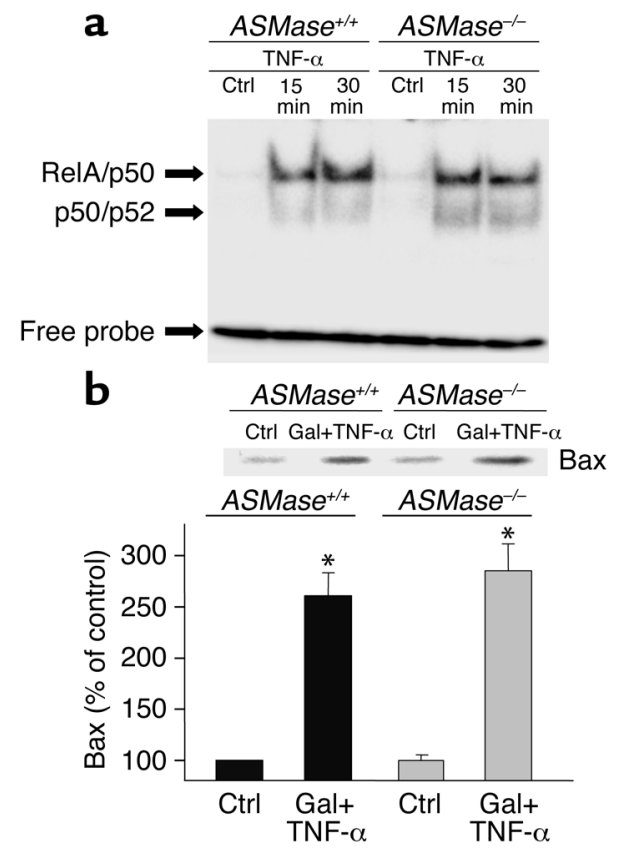

Figure 9

NF- $K B$ activation and mitochondrial Bax translocation in mouse hepatocytes. (a) Nuclear extracts from $\mathrm{ASMase}^{+/+}$and $\mathrm{ASMase}^{-/-}$hepatocytes after TNF- $\alpha$ exposure were prepared and used for NF- $\mathrm{\kappa B}$ activation using a consensus oligonucleotide. (b) Hepatocytes were treated with galactosamine plus TNF- $\alpha(280 \mathrm{ng} / \mathrm{ml})$ for 16 hours. Cells were then fractionated to prepare mitochondria as described in the Methods. Bax levels in the mitochondrial fraction were analyzed by Western blotting and quantitated by densitometry. Results are expressed as means $\pm \mathrm{SD}\left(n=4\right.$ independent experiments). ${ }^{*} P<0.05$ versus control. Gal + TNF- $\alpha$, galactosamine plus TNF- $\alpha$.

potentiated upon depletion of mGSH by HP pre-exposure (Figure 8). Furthermore, these findings were accompanied by increased caspase 3 activity, which was potentiated by HP pretreatment in agreement with previous results in cultured rat hepatocytes $(40,42)$. Taken together, these findings indicate that TNF- $\alpha$ signals the mitochondrial targeting of GD3 and that this process is likely involved in cell death.

$N F-\kappa B$ activation and mitochondrial Bax translocation in ASMase-deficient hepatocytes. To examine whether the resistance of ASMase-/- hepatocytes to TNF- $\alpha$ is related to deficient signaling upstream of mitochondria, we examined the activation of NF- $\mathrm{KB}$ and the translocation of Bax to mitochondria. TNF- $\alpha$ enhanced the DNA binding activity of NF-kB in nuclear extracts in both $\mathrm{ASMase}^{+/+}$and ASMase ${ }^{-/}$hepatocytes (Figure 9a). Furthermore, the levels of Bax detected in the mitochondrial fraction after TNF- $\alpha$ administration was similar in both wild-type and ASMase-deficient hepatocytes (Figure 9b). Moreover, similar results were observed in rat hepatocytes in which endogenous ASMase was inactivated by imipramine without impairment in the activation of NF-KB nor mitochondrial translocation of Bax induced by TNF- $\alpha$ (data not shown). Hence, these findings indicate that signaling events upstream of mitochondria induced by TNF- $\alpha$ are preserved in hepatocytes lacking ASMase.

\section{Discussion}

The present study was undertaken to specifically address the role of ASMase in the apoptotic signaling of TNF- $\alpha$ in hepatocytes. TNF- $\alpha$ apoptotic signaling is a complex process that involves protein-protein interactions and the participation of several intermediates. Sphingolipid generation through SMase activation has been involved in apoptotic pathways induced by death ligands (17-20, 23). We provide compelling evidence that ASMase plays an important contributory role in TNF- $\alpha$-mediated hepatocellular apoptosis. Because of the intrinsic resistance of primary hepatocytes to TNF- $\alpha$, survival pathways must be antagonized to unmask the efficient apoptotic ability of TNF- $\alpha$. Hepatocytes selectively depleted of mGSH levels using HP, which generates a Michael acceptor within mitochondria that is conjugated with the endogenous mGSH pool $(53,54)$, become susceptible to induction by TNF- $\alpha$ of both apoptotic and necrotic cell death. Both forms of cell death, however, were prevented by cyclosporin A, indicating the relevance of MPT in initiating either outcome of cell demise (67).

ASMase contributes to TNF- $\alpha$-induced hepatocellular apoptosis. To address the role of ASMase in apoptotic signaling by TNF- $\alpha$, we used two distinct approaches. The first approach was the inactivation of endogenous hepatocellular ASMase, and the second was the use of hepatocytes from ASMase knockout mice. Both strategies indicated resistance to TNF- $\alpha$-mediated cell death.

The role of individual SMases - namely, NSMase and ASMase - in death ligand-induced apoptosis is controversial and not well established. In focusing on TNF- $\alpha$-mediated apoptosis, previous studies have shown that FAN, an adapter factor associated with NSMase activation (68), is involved in TNF- $\alpha$-induced apoptosis in fibroblasts (27). Although these data clearly show an important role of NSMase in TNF- $\alpha-$ induced apoptosis in fibroblasts, the fate of FAN-deficient hepatocytes in TNF- $\alpha$-mediated cell death was not examined. Consistent with the ability of TNF- $\alpha$ to activate both NSMase and ASMase $(17,23)$, we observed that TNF- $\alpha$ stimulated NSMase activity in hepatocytes deficient in ASMase. Thus, although our present data argue for a critical role of ASMase in TNF- $\alpha$-mediated hepatocellular cell death, at present we cannot rule out an indirect contributory role of NSMase. Whether or not TNF- $\alpha$ requires both SMases for optimal cell-death induction requires further investigation.

ASMase needs an acidic $\mathrm{pH}$ environment for optimal function, and according to this functional requirement, ASMase is assumed to reside in acidic vesicles or compartments $(22,23)$. In studies that exploit this feature, the role of acidic compartments in TNF- $\alpha$-mediated cell death has been recognized in U937 and L929 cells (69). Moreover, we have previously reported that monensin prevents the burst of mitochondrial reactive oxygen species (ROS) generation and hepatocellular cell death by human placental ASMase (49). Recently, it has been shown that cathepsin B, a lysosomal 
enzyme, plays an important role in TNF- $\alpha$-mediated apoptosis in hepatocytes (45). Our current study adds to these reports, indicating an important function of acidic components for efficient TNF- $\alpha$-induced hepatocellular apoptosis. In addition to the participation of these components, hepatocytes deficient in Bid, a BH3only member of the Bcl-2 family, exhibited resistance to TNF- $\alpha$ and Fas-induced hepatocellular injury (46). Taken together, these observations indicate the participation of several partners (including at least Bid, cathepsin B, and ASMase) for optimal TNF- $\alpha$-mediated cell death in hepatocytes. The functional interplay between these players in TNF- $\alpha$ apoptotic signaling remains to be elucidated.

Signaling events upstream of mitochondria are preserved in ASMase-deficient hepatocytes. Having observed that ASMase is necessary for efficient TNF- $\alpha$-mediated hepatocellular damage, we tested whether the absence of ASMase interfered with known effectors of TNF- $\alpha$ action. Our results show that the activation of NF- $\mathrm{KB}$, which occurs early during TNF- $\alpha$ signaling, is comparable between SSMase $^{+/+}$and ASMase ${ }^{-/-}$hepatocytes. In agreement with these findings, previous studies reported that the activation pattern of $\mathrm{p} 38$, JNK, and extracellular signal-regulated kinases in response to epidermal growth factor or TNF- $\alpha$ were similar in $\mathrm{ASMase}^{+/+}$ and $A S M a s e^{-/-}$mice (35). Moreover, a requirement has been shown for BH1-3 multidomain Bcl-2 family members, Bax or Bak, for the efficient apoptosis induced by a variety of inducing signals (70). Bax is predominantly localized in the cytosol of healthy cells and translocates to mitochondria after apoptotic stimulation because of a conformational change in the $\mathrm{N}$ and $\mathrm{C}$ termini of Bax that results in its translocation, oligomerization or cluster formation, and integration into the mitochondrial membranes (71). We determined the levels of Bax in the mitochondrial fraction of $\mathrm{ASMase}^{-/-}$in response to TNF- $\alpha$ to ascertain whether this critical step was missing or defective. Unexpectedly, our findings indicate that the translocation of Bax to mitochondria was unimpaired in hepatocytes deficient in ASMase. These results therefore indicate that the translocation of BH1-3 multidomain Bcl-2 family members - for example, Bax - appears to be independent of ASMase, yet downstream steps of mitochondria, including cytochrome $c$ release and caspase activation, seem to require ASMase. Further work will be needed to address these fundamental questions. Perhaps through altered ceramide generation and/or sphingomyelin metabolism, ASMase may contribute to the maintenance of a mitochondrial lipid environment adequate for the proper mitochondrial docking of Bax to facilitate the apoptosome.

Glycosphingolipids contribute to TNF- $\alpha$-induced apoptosis. In pursuing the mechanisms involved in linking ASMase to mitochondria during TNF- $\alpha$ apoptotic signaling in hepatocytes, we addressed the relative contribution of ceramide versus glycosphingolipids, two major products of ASMase. Previous studies have shown that ceramide interacts with isolated mitochondria, impairing mitochondrial respiration and stimulating ROS formation and MPT onset (55, 72-74). On the other hand, disialoganglioside GD3 has been shown to interact with mitochondria in vitro, leading to MPT, cytochrome $c$ release, and caspase activation (38-42). To discern the participation of these putative mitochondria-interacting lipids in TNF- $\alpha$ apoptotic signaling, we blocked the synthesis of gangliosides and analyzed the survival of hepatocytes during TNF- $\alpha$ exposure. Inhibition of glucosylceramide synthase, a resident Golgi enzyme that forms glucosylceramide, the precursor for complex glycosphingolipid synthesis (75), results in depressed basal and TNF- $\alpha-$ stimulated glycolipid levels, while, consequently, leading to increased basal and enhanced TNF- $\alpha$-stimulated ceramide levels. Unexpectedly, HP-sensitized hepatocytes become protected against TNF- $\alpha$ in the presence of d-threo-PDMP despite the fact that ceramide accumulated twofold with respect to the stimulation of ceramide induced by TNF- $\alpha$ itself. Hence, although these results minimize the participation of ceramide itself in the targeting and subsequent engagement of mitochondria in the TNF- $\alpha$ cell-death pathway, it may be conceivable that both lipids (ceramide and glycosphingolipids, e.g., GD3) may be required for optimal cytotoxic activity of TNF- $\alpha$. The relative contribution of ceramide versus glycosphingolipids in apoptosis and cell death may be dependent on the cellular context in which these sphingolipids are generated (76). Furthermore, the monitoring of the cellular distribution of GD3 during TNF- $\alpha$ signaling indicated its mitochondrial targeting in $\mathrm{ASMase}^{+/+}$but not in $A S M a s e^{-/-}$hepatocytes, suggesting that ASMase is necessary for this event. In further support for this interpretation, exogenous ASMase induced both the mitochondrial targeting of GD3 in ASMase ${ }^{-/-}$hepatocytes and the sensitization of these cells to exogenous ASMase exposure, and, as expected, ASMase ${ }^{-/-}$mice were sensitive to GD3 in agreement with previous results $(38,40,42)$. Moreover, recent findings in cultured rat hepatocytes showed that the targeting of GD3 to mitochondria induced by TNF- $\alpha$ occurred within 1 hour after incubation (61), well before the activation of caspase 3 , indicating that the formation of GD3 and its subsequent translocation to mitochondria initiated the molecular mechanisms of cell death. In line with this outcome in hepatocytes, a recent study has shown that GD3 contributes to Fas-mediated apoptosis, reporting the colocalization of GD3 with mitochondria in lymphoid cells (77). Thus, although our data support a role for GD3 synthesized from ASMase in the apoptotic signaling by TNF- $\alpha$, at present we cannot discard the involvement of other glycosphingolipids derived from ASMase in this process. Other related glycosphingolipids share the structural features of GD3 for its mitochondria-interacting function (42). However, as shown previously, the downregulation of targeted GD3 synthase, the enzyme responsible for GD3 synthesis 
from GM3, protected lymphoid cells against Fas-mediated apoptosis (37) or human colon HT-29 cells against TNF- $\alpha$-induced apoptosis (78).

Hence, our findings indicate a sequence of events initiated by the mitochondrial targeting of GD3 generated from ASMase-induced ceramide by TNF- $\alpha$. GD3 then permeabilizes mitochondria, setting in motion the molecular pathways leading to apoptotic and necrotic cell death.

As referred to above, our data indicate that although GD3 reaches mitochondria in hepatocytes in response to TNF- $\alpha$, the consequences of this interaction are controlled by mGSH levels. The sensitization of $\mathrm{mGSH}-$ depleted hepatocytes to either TNF- $\alpha$ or exogenous human placental ASMase indicates that $\mathrm{mGSH}$ regulates cell survival by modulating MPT through control of an appropriate redox environment. Increased mitochondrial ROS formation may induce MPT opening through the targeting of susceptible sulfhydryl groups of MPT components (79). The relevance of mGSH for hepatocyte survival in response to TNF- $\alpha$ may be of therapeutic significance for the treatment of alcoholinduced liver disease. Increased TNF- $\alpha$ levels are important for the progression of alcohol-induced liver damage (80), and hepatocytes from chronically alcohol-fed rats, which exhibit depleted $\mathrm{mGSH}$, are susceptible to TNF- $\alpha$-mediated cell death $(54,81-83)$. According to our present data, strategies aimed to reduce or antagonize TNF- $\alpha$-stimulated glycosphingolipid generation and/or to replenish mGSH levels may prevent or diminish the susceptibility of the liver to alcohol consumption.

\section{Acknowledgments}

We want to thank E. Gulbins and R. Kolesnick for the generous gift of $\mathrm{ASMase}^{-/-}$mice and A. Serrano for antimitochondrial serum. The technical assistance of A. Bosch and M. Taulés from Serveis Cientifics Tecnics in confocal and immunoelectron microscopy studies, as well as S. Nuñez and O. Coll for technical help with cell cultures and mouse genotyping is recognized. This work was supported in part by the Research Center for Liver and Pancreatic Diseases (P50 AA11999) and grant 1R21 AA014135-01 funded by the U.S. National Institute on Alcohol Abuse and Alcoholism; Plan Nacional de I+D grants SAF 99-0138, 2FD97-0988, and PM99-0166; and Fondo Investigaciones Sanitarias grant FISS 00-907. C. García-Ruiz is a Sistema Nacional de Salud investigator from the Fondo Investigaciones Sanitarias.

1. Smith, C.A., Farrah, T., and Goodwin, R.G. 1994. The TNF receptor superfamily of cellular and viral proteins: activation, costimulation, and death. Cell. 76:959-962.

2. Krammer, P.H. 1999. CD95(APO-1/Fas)-mediated apoptosis: live and let die. Adv. Immunol. 71:163-210.

3. Kroemer, G., and Reed, J.C. 2000. Mitochondrial control of cell death. Nat. Med. 6:513-519.

4. Faubion, W.A., and Gores, G.J. 1999. Death receptors in liver biology and pathobiology. Hepatology. 29:1-4.

5. Green, D.R., and Reed, J.C. 1998. Mitochondria and apoptosis. Science. 281:1309-1312.

6. Gross, A., McDonnell, J.M., and Korsmeyer, S.J. 1999. Bcl-2 family members and the mitochondria in apoptosis. Genes Dev. 13:1899-1911.
7. Brenner, C., and Kroemer, G. 2000. Mitochondria - the death signal integrators. Science. 289:1150-1151.

8. Bradham, C.A., et al. 1998. The mitochondrial permeability transition is required for tumor necrosis factor alpha-mediated apoptosis and cytochrome c release. Mol. Cell. Biol. 18:6353-6364.

9. Li, H., et al. 2000. Cytochrome c release and apoptosis induced by mitochondrial targeting of nuclear orphan receptor TR3. Science. 289:1159-1164.

10. Jacotot, E., et al. 2001. Control of mitochondrial membrane permeabilization by adenine nucleotide translocator interacting with HIV-1 viral protein $\mathrm{r}$ and Bcl-2. J. Exp. Med. 193:509-520.

11. Yoshida, H., et al. 1998. Apaf 1 is required for mitochondrial pathways of apoptosis and brain development. Cell. 94:739-750.

12. Li, K., et al. 2000. Cytochrome c deficiency causes embryonic lethality and attenuates stress-induced apoptosis. Cell. 101:389-399.

13. Susin, S.A., et al. 1999. Mitochondrial release of caspase-2 and -9 during the apoptotic process. J. Exp. Med. 189:381-394.

14. Susin, S.A., et al. 1999. Molecular characterization of mitochondrial apoptosis-inducing factor. Nature. 397:441-446.

15. Du, C., Fang, M., Li, Y., Li, L., and Wang, X. 2000. Smac, a mitochondrial protein that promotes cytochrome c-dependent caspase activation by eliminating IAP inhibition. Cell. 102:33-42.

16. Verhagen, A.M., et al. 2000. Identification of DIABLO, a mammalian protein that promotes apoptosis by binding to and antagonizing inhibitor of apoptosis (IAP) proteins. Cell. 102:43-53.

17. Hannun, Y.A., and Luberto, C. 2000. Ceramide in the eukaryotic stress response. Trends Cell Biol. 10:73-80.

18. Hannun, Y.A., Luberto, C., and Argraves, K.M. 2001. Enzymes of sphingolipid metabolism: from modular to integrative signaling. Biochemistry. 40:4893-4903.

19. Merrill, A.H., Jr., Lingrell, S., Wang, E., Nikolova-Karakashian, M.N., and Vance, D. 1995. Sphingolipid biosynthesis de novo by rat hepatocytes in culture. Ceramide and sphingomyelin are associated with, but not required for, very low-density lipoprotein secretion. J. Biol. Chem. 270:13834-13841.

20. Spiegel, S., and Merrill, A.H., Jr. 1996. Sphingolipid metabolism and growth regulation. FASEB J. 10:1388-1397.

21. Wiegman, K., Schutze, S., Machleidt, T., Witte, D., and Kronke, M. 1994. Functional dichotomy of neutral and acidic sphingomyelinase in tumor necrosis factor signaling. Cell. 78:1005-1015.

22. Liu, P., and Anderson, G.G.W. 1995. Compartmentalized production of ceramide at the cell surface. J. Biol. Chem. 270:27179-27185.

23. Kolesnick, R.N., and Kronke, M. 1998. Regulation of ceramide production and apoptosis. Annu. Rev. Physiol. 60:643-665.

24. Schissel, S.L., Schuchman, E.H., Williams, K.J., and Tabas, I. 1996. Zn+ stimulated sphingomyelinase is secreted by many cells and is a product of the acid sphingomyelin gene. J. Biol. Chem. 271:18431-18436.

25. Bezombes, C., et al. 2001. Lysosomal sphingomyelinase is not solicited for apoptotic signaling. FASEB J. 15:297-299.

26. Zhang, P., Liu, B., Jenkins, G.M., Hannun, Y.A., and Obeid, L.M. 1997. Expression of neutral sphingomyelinase identifies a distinct pool of sphingomyelin involved in apoptosis. J. Biol. Chem. 272:9609-9612.

27. Segui, B., et al. 2001. Involvement of FAN in TNF-induced apoptosis. J. Clin. Invest. 108:143-151. doi:10.1172/JCI200111498.

28. Morita, Y., et al. 2000. Oocyte apoptosis is suppressed by disruption of the acid sphingomyelinase gene or by sphingosine-1-phosphate therapy. Nat. Med. 6:1109-1114.

29. Lozano, J., et al. 2001. Cell autonomous apoptosis defects in acid sphingomyelinase knockout fibroblasts. J. Biol. Chem. 276:442-448.

30. Strelow, A., et al. 2000. Overexpression of acid ceramidase protects from tumor necrosis factor induced cell death. J. Exp. Med. 192:601-611.

31. Higuchi, M., Singh, S., Jaffrezou, P., and Aggarwal, B.B. 1996. Acidic sphingomyelinase-generated ceramide is needed but not sufficient for TNF-induced apoptosis and nuclear factor-kappa B activation. J. Immunol. 156:297-304.

32. Grullich, C., Sullards, M.C., Fuks, Z., Jr., Merrill, A.H., and Kolesnick, R. 2000. CD95(Fas/APO-1) signals ceramide generation independent of the effector stage of apoptosis. J. Biol. Chem. 275:8650-8656.

33. Lin, T., et al. 2000. Role of acidic sphingomyelinase in Fas/CD95-mediated cell death. J. Biol. Chem. 275:8657-8663.

34. De Maria, R., Rippo, M.R., Schuchmann, E.H., and Testi, R. 1998. Acidic sphingomyelinase is necessary for Fas-induced GD3 ganglioside accumulation and efficient apoptosis of lymphoid cells. J. Exp. Med. 187:897-902.

35. Paris, F., et al. 2001. Natural ceramide reverses Fas resistance of acid sphingomyelinase ${ }^{-/-}$hepatocytes. J. Biol. Chem. 276:8297-8305.

36. Boesen-de-Cock, J.G.R., Tepper, A.D., de Vries, E., van Wlitterswijk, W.J., and Borst, J. 1998. CD95 (Fas/APO-1) induces ceramide formation and apoptosis in the absence of functional acid sphingomyelinase. J. Biol. Chem. 273:7560-7565.

37. DeMaria, R., et al. 1997. Requirement for GD3 ganglioside in ceramideinduced apoptosis. Science. 277:1652-1655. 
38. Scorrano, L., Petronilli, P., DiLisa, F., and Bernardi, P. 1999. Commitment to apoptosis by GD3 ganglioside depends on opening of the mitochondrial permeability transition pore. J. Biol. Chem. 274:22581-22585.

39. Kristal, B.S., and Brown, A. 1999. Apoptogenic ganglioside GD3 directly induces the mitochondrial permeability transition. J. Biol. Chem. 274:23169-23175

40. García-Ruiz, C., Colell, A., París, R., and Fernández-Checa, J.C. 2000. Direct interaction of GD3 ganglioside with mitochondria generates reactive oxygen species followed by mitochondrial permeability transition, cytochrome c release and caspase activation. FASEB J. 14:847-858.

41. Rippo, M.R., et al. 2000. GD3 ganglioside directly targets mitochondria in a bcl-2 controlled fashion. FASEB J. 14:2047-2054.

42. Colell, A., García-Ruiz, C., Roman, J., Ballesta, A., and Fernández-Checa, J.C. 2001. Ganglioside GD3 enhances apoptosis by suppressing the nuclear factor-КB-dependent survival pathway. FASEB J. 15:1068-1070.

43. Lavie, Y., Cao, H., Bursten, S.L., Giuliano, A.E., and Cabot, M.C. 1996. Accumulation of glucosylceramides in multidrug-resistant cancer cells. J. Biol. Chem. 271:19530-19536.

44. Lavie, Y., et al. 1997. Agents that reverse multidrug resistance, tamoxifen, verapamil and cyclosporin A, block glycosphingolipid metabolism by inhibiting ceramide glycosylation in human cancer cells. J. Biol. Chem. 272:1682-1687.

45. Guicciardi, M.E., et al. 2000. Cathepsin B contributes to TNF- $\alpha$-mediated hepatocyte apoptosis by promoting mitochondrial release of cytochrome c. J. Clin. Invest. 106:1127-1137.

46. Zhao, Y., Li, Z., Childs, E.E., Kuharsky, D.K., and Yin, X.-M. 2001. Activation of pro-death $\mathrm{Bcl}-2$ proteins and mitochondria apoptosis pathway in tumor necrosis factor- $\alpha$-induced liver injury. J. Biol. Chem. 276:27432-27440.

47. Horinouchi, K., et al. 1995. Acid sphingomyelinase deficient mice: a model of types A and B Niemann-Pick disease. Nat. Genet. 10:288-293.

48. Morales, A., et al. 1997. Tumor necrosis factor increases hepatocellular glutathione by transcriptional regulation of the heavy subunit chain of $\gamma$-glutamylcysteine synthetase. J. Biol. Chem. 272:30371-30379.

49. Garcia-Ruiz, C., et al. 2000. Human placenta sphingomyelinase, an exogenous acidic $\mathrm{pH}$-optimum sphingomyelinase, induces oxidative stress, glutathione depletion, and apoptosis in rat hepatocytes. Hepatology. 32:56-65.

50. Pukel, C.S., et al. 1982. GD3, a prominent ganglioside of human melanoma. Detection and characterization by mouse monoclonal antibody. J. Exp. Med. 155:1133-1147.

51. Clavería, C., et al. 1998. Drosophila grim induces apoptosis in mammalian cells. EMBO J. 17:7199-7208.

52. Ruiz-Vela, A., Gonzáles de Buitrago, G., and Martinez-A, C. 1999. Implication of calpain in caspase activation during $\mathrm{B}$ cell clonal deletion. EMBO J. 18:4988-4998.

53. Shan, X., Jones, D.P., Hashmi, M., and Anders, M.W. 1993. Selective depletion of mitochondrial glutathione concentrations by (R,S)-3hydroxy-4-pentenoate potentiates oxidative cell death. Chem. Res. Toxicol. 6:75-81.

54. Colell, A., et al. 1998. Selective glutathione depletion of mitochondria by ethanol sensitizes hepatocytes to tumor necrosis factor. Gastroenterology. 115:1541-1551.

55. García-Ruiz, C., Colell, A., Mari, M., Morales, A., and Fernández-Checa, J.C. 1997. Direct effect of ceramide on the mitochondrial electron transport chain leads to reactive oxygen species. Role of mitochondrial glutathione. J. Biol. Chem. 272:11369-11377.

56. Tiegs, G., et al. 1998. Ebselen protects mice against T cell-dependent, TNF-mediated apoptotic liver injury. J. Pharmacol. Exp. Therap. 287:1098-1104.

57. Wielockx, B., et al. 2001. Inhibition of matrix metalloproteinases blocks lethal hepatitis and apoptosis induced by tumor necrosis factor and allows safe antitumor therapy. Nat. Med. 7:1202-1208.

58. Hurwitz, R., Ferlinz, K., and Sandhoff, K. 1994. The tricyclic antidepressant desipramine causes proteolytic degradation of lysosomal sphingomyelinase. Biol. Chem. Hoppe Seyler. 375:447-450.

59. Grassme, H., et al. 1997. Acidic sphingomyelinase mediates entry of $N$. gonorrboeae into nonphagocytic cells. Cell. 91:605-615.

60. Goping, I.S., et al. 1998. Regulated targeting of BAX to mitochondria. J. Cell Biol. 143:207-215.
61. Garcia-Ruiz, C., et al. 2002. Trafficking of ganglioside GD3 to mitochondria by tumor necrosis factor- $\alpha$. J. Biol. Chem. 277:36443-36448.

62. Latta, M., Kunstle G., Leist, M., and Wendel, A. 2000. Metabolic depletion of ATP by fructose inversely controls CD95- and tumor necrosis factor receptor 1-mediated hepatic apoptosis. J. Exp. Med. 191:1975-1985.

63. Hentze, H., Gantner, F., Kolb, S.A., and Wendel, A. 2000. Depletion of hepatic glutathione prevents death receptor-dependent apoptotic and necrotic liver injury in mice. Am. J. Pathol. 156:2045-2056.

64. Nagai, H., Matsumaru, K., Feng, G., and Kaplowitz, N. 2002. Reduced glutathione depletion causes necrosis and sensitization to tumor necrosis factor- $\alpha$-induced apoptosis in cultured mouse hepatocytes. Hepatology. 36:55-64.

65. Hurwitz, R., Ferlinz, K., Vielhaber, G., Moczall, H., and Sandhoff, K 1994. Processing of human acid sphingomyelinase in normal and I cell fibroblasts. J. Biol. Chem. 269:5440-5445.

66. Jensen, J.-M., Schutze, S., Michael, F., Kronke, M., and Proksch, E. 1999. Roles for tumor necrosis factor receptor $\mathrm{p} 55$ and sphingomyelinase in repairing the cutaneous permeability barrier. J. Clin. Invest. 104:1761-1770.

67. Lemasters, J.J. 1999. Mechanisms of hepatic toxicity. V. Necrapoptosis and the mitochondrial permeability transition: shared pathways to necrosis and apoptosis. Am. J. Physiol. 276:G1-G6.

68. Adam-Klages, S., et al. 1996. FAN, a novel WD-repeat protein, couples the p55 TNF-receptor to neutral sphingomyelinase. Cell. 86:937-947.

69. Monney, L., et al. 1998. Role of an acidic compartment in tumor necrosis factor- $\alpha$-induced production of ceramide, activation of caspase 3 and apoptosis. Eur. J. Biochem. 251:295-303

70. Lindsten, T., et al. 2000. The combined functions of proapoptotic Bcl-2 family members bak and bax are essential for normal development of multiple tissues. Mol. Cell. 6:1389-1399.

71. Antonsson, B., Montessuit, S., Sanchez, B., and Martinou, J.C. 2001. Bax is present as a high molecular weight oligomer/complex in the mitochondrial membrane of apoptotic cells. J. Biol. Chem. 276:11615-11623.

72. Quillet-Mary, A., et al. 1997. Implication of mitochondrial hydrogen peroxide generation in ceramide-induced apoptosis. J. Biol. Chem. 272:21388-21395.

73. Gudz, T.I., Tserng, K.Y., and Hoppel, C.L. 1997. Direct inhibition of mitochondrial respiratory chain complex III by cell-permeable ceramide. J. Biol. Chem. 272:24154-24158.

74. Gharourifar, P., et al. 1999. Ceramide induces cytochrome $\mathrm{c}$ release from isolated mitochondria. Importance of mitochondrial redox state. J. Biol. Chem. 272:6080-6084.

75. Ichikawa, S., and Hirabayashi, Y. 1998. Glucosylceramide synthetase and glycosphingolipid synthesis. Trends Cell Biol. 8:198-203.

76. Kolesnick, R. 2002. The therapeutic potential of modulating the ceramide/sphingomyelin pathway. J. Clin. Invest. 110:3-8. doi:10.1172/JCI200216127.

77. Giammaroli, A.M., et al. 2001. GD3 glycosphingolipid contributes to Fas-mediated apoptosis via association with ezrin cytoskeletal protein. FEBS Lett. 506:45-50.

78. Colell, A., Morales, A., Fernández-Checa, J.C., and Garcia-Ruiz, C. 2002. Ceramide generated by acidic sphingomyelinase contributes to tumor necrosis factor- $\alpha$-mediated apoptosis in human colon HT-29 cells through glycosphingolipid generation. Possible role of ganglioside GD3 FEBS Lett. 526:135-141.

79. Costantini, P., et al. 2000. Oxidation of a critical thiol residue of the adenine nucleotide translocator enforces $\mathrm{Bcl}$-2-independent permeability transition pore opening and apoptosis. Oncogene. 13:307-314.

80. Yin, M., et al. 1999. Essential role of tumor necrosis factor in alcoholicinduced liver injury in mice. Gastroenterology. 117:942-952.

81. Fernández-Checa, J.C., García-Ruiz, C., Ookhtens, M., and Kaplowitz, N. 1991. Impaired uptake of glutathione by hepatic mitochondria from chronic ethanol-fed rats. J. Clin. Invest. 87:397-405.

82. García-Ruiz, C., et al. 1994. Effect of chronic ethanol feeding on glutathione and functional integrity of mitochondria in periportal and perivenous rat hepatocytes. J. Clin. Invest. 94:193-201.

83. Pastorino, J.G., and Hoek, J.W. 2000. Ethanol potentiates tumor necrosis factor cytotoxicity in hepatoma cells and primary rat hepatocytes by promoting induction of the mitochondrial permeability transition. Hepatology. 31:1141-1152. 